\title{
PELATIHAN PEMBUATAN YOGHURT DARI SUSU BUBUK INSTAN FULL CREAM PADA IBU-IBU KOTA PELANGI DI PANCORAN, JAKARTA SELATAN
}

\author{
Laras Cempaka ${ }^{1 *}$, Nurul Asiah ${ }^{2}$, \\ ${ }^{12}$ Program Studi IImu dan Teknologi Pangan, Fakultas Teknik dan Ilmu Komputer, Universitas Bakrie, Indonesia \\ E-mail: ${ }^{1}$ laras.cempaka@bakrie.ac.id*, 2nurul.asiah@bakrie.ac.id
}

Received: March 4, 2020 / Revised: June 29, 2020 / Accepted: June 30, 2020

DOI: https://doi.org/10.36782/ijsr.v2i1.25

\begin{abstract}
ABSTRAK
Yoghurt merupakan minuman berbahan baku susu yang difermentasikan oleh bakteri asam laktat. Umumnya susu yang digunakan adalah susu segar. Yoghurt menjadi produk minuman yang dipilih karena rasanya yang khas dan khasiat yang dimilikinya. Tujuan dari kegiatan ini adalah untuk memberikan pelatihan pembuatan yoghurt dari bahan baku susu yang mudah didapat yaitu susu bubuk instan full cream kepada Ibu-Ibu UKM Kota Pelangi. Yoghurt yang dibuat dari susu bubuk ini dilakukan dengan dua tahap yaitu penyampaian materi dan praktek simulasi pembuatan yoghurtnya. Pelatihan dengan pengamatan secara observatif ini dilaksanakan di salah satu rumah anggota UKM Kota Pelangi di wilayah Pancoran, Jakarta Selatan. Sampel yoghurt yang sudah jadi kemudian dikreasikan dengan toping dan perisa yang berbeda. Pembuatan yoghurt dilakukan bersama susu yang sudah ditambah kultur bakteri lalu diinkubasi dalam waktu 12-14 jam. Selain membekali peserta dari sisi kemampuan pengolahan, pengetahuan tentang proses fermentasi dan aspek mikrobiologi yang baik juga perlu dipahami, agar produk yang dihasilkan memiliki kualitas yang baik. Para peserta antusias dalam menyimak pemaparan dari sejumlah pemateri. Dalam praktek simulasi, peserta membuat yoghurt dan mengkreasikannya dengan aneka rasa maupun toping yang dibuat semenarik mungkin. Kesan dari para peserta, yoghurt yang dibuat dari susu bubuk ini tetap memiliki rasa yang enak dan tekstur yang sesuai. Pelatihan semacam ini sangat baik sekali dilakukan pada daerah yang memiliki keterbatasan sumber daya bahan baku untuk diolah menjadi aneka pangan olahan.
\end{abstract}

Kata kunci: Minuman Fermentasi, Pelatihan, Produk Pangan, Susu Bubuk Instan Full Cream, Yoghurt.

\section{ABSTRACT}

Yogurt is a beverage made from milk which is fermented by lactic acid bacteria. Generally the milk used is fresh milk. Yogurt is the chosen beverage product because of its distinctive taste and properties. The purpose of this activity is to provide training in making yogurt from raw milk ingredients that are easily obtainable, namely full cream instant milk powder to the City of Pelangi UKM. Yogurt made from milk powder is done in two stages, namely the delivery of material and the practice of making yogurt. This observational observation training was held in one of the homes of Pelangi City UKM members in the Pancoran area, South Jakarta. The finished yogurt sample is then created with different topings and flavors. Making yogurt is done with milk that has been added to bacterial culture and then incubated within 12-14 hours. In 
addition to equipping participants in terms of processing capability, good knowledge of the fermentation process and microbiological aspects also needs to be understood, so that the products produced have good quality. The participants were enthusiastic in listening to the presentation of a number of presenters. In simulation practice, participants make yogurt and create it with various flavors and topings that are made as attractive as possible. The impression from the participants, the yogurt made from milk powder still has a good taste and an appropriate texture. This kind of training is very well done in areas that have limited raw material resources to be processed into various processed foods.

Keywords: Fermented Beverages, Training, Food Product, Instant Milk Powder, Yogurt.

\section{PENDAHULUAN}

Kegiatan perekonomian tidak hanya dapat diciptakan dari industri besar, namun dapat dilakukan pada skala kecil dan menengah. Saat ini banyak sekali potensi pengembangan usaha yang dapat dilakukan dari skala usaha mikro, kecil dan menengah (UMKM). Potensi sumber daya alam menjadi salah satu parameter keberhasilan usaha yang dapat dikembangkan oleh individu yang berada pada wilayah tersebut. Termasuk pada kelompok Ibu-Ibu UKM Kota Pelangi di Kecamatan Pancoran, Jakarta Selatan, yang memiliki komunitas usaha bersama. Salah satu potensi produk yang dapat dikembangkan yaitu yoghurt. Yoghurt dipercaya sebagai minuman kesehatan karena mengadung probiotik yang dapat melancarkan sistem pencernaan tubuh manusia.

Potensi minuman yoghurt untuk dikembangkan skala rumah tangga pada Kota Pelangi ini cukup baik, mengingat saat ini perkembangan minuman di masyarakat berkembang pesat. Minuman teh, cokelat, kopi dengan varian yang beragam sangat digemari terutama untuk generasi milenial. Dengan dikembangkannya minuman berbasis yoghurt atau susu fermentasi ini diharapkan dapat memberi alternatif untuk konsumen dalam memilih minuman yang enak, menyegarkan namun tetap memberikan manfaat yang baik untuk tubuh.

Produk yang disukai oleh segala kalangan usia ini bukan tidak mungkin akan menggantikan posisi minuman kekinian. Namun, UKM yang terletak di wilayah perkotaan cukup sulit untuk mendapat bahan baku pembuatan yoghurt yaitu susu segar karena berada jauh dari wilayah peternakan. Hal ini dialami oleh UKM Kota Pelangi yang selain berada di wilayah perkotaan juga berada di lingkungan yang strategis di kota besar DKI Jakarta. Potensi daerah Jakarta tidak seperti pada kota-kota lain yang cocok dengan iklim peternakan. Sehingga untuk membuat yoghurt dari susu segar sangat riskan dilakukan, mengingat susu segar merupakan komoditas yang sangat mudah rusak atau cepat membusuk. Dengan demikian, perlu adanya bahan baku alternatif untuk membuat yoghurt, diantaranya adalah penggunaan susu bubuk instan full cream 
dan kultur yoghurt yang berasal dari yoghurt plain.

Pelatihan merupakan sarana untuk meningkatkan kompetensi peserta agar dapat dengan mudah mempraktekan keterampilan yang akan dimilikinya. Selain itu, dengan adanya pelatihan, akan memberikan ruang kepada peserta untuk membangun komunitas yang sesuai dengan tujuan yang dibangun bersama (Jatmika dan Hastuti, 2019).

Pelatihan ini sangat terkait dengan visi dan misi Kota Pelangi yaitu visi menjadikan komunitas Kota Pelangi sebagai role model kegiatan pemberdayaan perempuan yang mandiri dan memiliki nilai kebermanfaatan secara luas.

Misi yang mereka miliki diantaranya adalah memberikan pendampingan terkait dengan inovasi produk, branding, pengemasan, pemasaran, manajemen keuangan hingga izin usaha yang dinilai mampu meningkatkan nilai jual usaha, memberikan pendampingan untuk melihat potensi produk yang dimiliki dan potensi pasar yang sedang terjadi, melakukan monitoring dan evaluasi secara berkala sebagai bentuk pendampingan dan pengembangan kegiatan usaha, membantu memfasilitasi berbagai kebutuhan terkait pendampingan lain yang dinilai berpengaruh baik untuk usaha.

Berwirausaha tentu akan menghadapi segala macam tantangan dan hambatan. Tidak terkecuali dengan keterbatasan sumber daya alam. Solusinya adalah bagaimana memberikan alternatif terhadap bahan baku yang tersedia. Seperti yang akan dilakukan dalam program PkM kali ini. Program PkM ini mengusung tema produksi yoghurt dengan menggunakan susu bubuk instan full cream. Daerah DKI Jakarta merupakan wilayah yang terbilang jauh dari peternakan. Untuk potensi yang terkait dengan hasil peternakan sangat sulit untuk dikembangkan. Namun, pada pembuatan susu fermentasi ini penggunaan sumber bahan baku susu bubuk instan full cream menjadi alternatif. Yoghurt dikenal dengan minuman kesehatan yang kaya akan probiotik.

Tujuan dari kegiatan ini adalah untuk memberikan pelatihan mengenai pembuatan yoghurt dari susu bubuk instan full cream sehingga dapat dimanfaatkan oleh masyarakat UKM Kota Pelangi bagi konsumsi pribadi atau untuk dijual kembali.

\section{TINJAUAN KEGIATAN DAN LITERATUR}

Yoghurt adalah salah satu produk fermentasi berbahan dasar susu. Pada awalnya yoghurt dibuat dari susu hewan ternak seperti susu sapi atau susu kambing dengan bentuk seperti bubur atau es krim. Proses pembuatannya adalah, susu difermentasi menggunakan bakteri Lactobacillus bulgaricus dan Streptococcus thermophillus dan didalamnya terdapat kultur aktif bakteri tersebut (Widowati dan Misgiyarta, 2009). Yoghurt merupakan olahan susu dari hasil fermentasi kedua dari Bakteri Asam Laktat (BAL) sebagai starter, yakni Sterptococcus thermophillus dan 
Lactobacillus bulgaricus yang hidup bersimbiosis. Lama proses fermentasi akan berakibat pada turunnya $\mathrm{pH}$ yoghurt dengan rasa asam yang khas, selain itu dihasilkan asam asetat, asetal dehid, dan bahan lain yang mudah menguap. Komposisi yoghurt secara umum adalah protein 4-6\%, lemak 0,1-1\%, laktosa 2-3\%, asam laktat 0,6-1,3\%, pH 3,8-4,6\% (Susilorini dan Sawitri, 2007). Menurut Deeth dan Tamime (1981) yoghurt mengandung beberapa kandungan antara lain: energi, protein, lemak, karbohidrat. Bahkan mengandung mineral (kalsium, fosfor, natrium, dan kalium) dan mempunyai kandungan vitamin cukup lengkap yaitu: vitamin A, B kompleks, B1 (thiamin), B2 (riboflavin), B6 (piridoksin), B12 (sianokobalamin), vitamin C, vitamin $D, E$, asam folat, asam nikotinat, asam pantotenat, biotin dan kolin. Keberadaan protein yang mudah dicerna serta asam laktat yang meningkatkan penyerapan mineral, membuat yoghurt baik dikonsumsi oleh anak dengan gangguan penyerapan di saluran erna (Rinadya, 2008).

Yoghurt merupakan produk susu yang mengalami fermentasi oleh bakteri asam laktat pada suhu $37-45^{\circ} \mathrm{C}$. Yoghurt sangat bermanfaat bagi tubuh, baik untuk memperoleh nilai nutrisi juga memberikan manfaat kesehatan terutama bagi pencernaan dimana bakteri-bakteri yoghurt yang masuk akan menyelimuti dinding usus sehingga dinding usus menjadi asam dan kondisi ini menyebabkan mikroba-mikroba pathogen tidak dapat berkembangbiak (Surono, 2004).
Yoghurt mempunyai nilai gizi yang tinggi dari pada susu segar sebagai bahan dasar dalam pembuatan yoghurt, terutama karena meningkatnya total padatan sehingga kandungan zat-zat gizi lainnya meningkat, selain itu yoghurt sesuai bagi penderita lactose Intolerance atau yang tidak toleran terhadap laktosa (Wahyudi, 2006). Pada dasar proses pembuatan yoghurt adalah memfermentasikan susu dengan menggunakan biakan (Streptococcus thermophilus) dan (Lactobacillus bulgaricus). Susu yang akan difermentasikan harus dipanaskan terlebih dahulu dengan tujuan untuk menurunkan populasi mikrobia dalam susu dan memberikan kondisi yang baik bagi pertumbuhan biakan yoghurt serta mengurangi kandungan air dalam susu (Rukmana, 2001). Proses pembuatannya adalah, susu difermentasi menggunakan bakteri Lactobacillus bulgaricus dan Streptococcus termophilus dan didalamnya terdapat kultur aktif bakteri tersebut (Widowati dan Misgiyarta, 2009). Menurut Winarno (2003), dasar fermentasi susu atau pembuatan yoghurt adalah proses fermentasi komponen gula-gula yang ada di dalam susu, terutama laktosa menjadi asam laktat dan asam-asam lainnya. Asam laktat yang dihasilkan selama proses fermentasi dapat meningkatkan citarasa dan meningkatkan keasaman atau menurunkan $\mathrm{pH}$ nya. Semakin rendahnya $\mathrm{pH}$ atau derajat keasaman susu setelah fermentasi akan menyebabkan semakin sedikitnya mikroba yang mampu bertahan hidup dan menghambat proses 
pertumbuhan mikroba patogen dan mikroba pengrusak susu, sehingga umur simpan susu dapat menjadi lebih lama. Kualitas yoghurt dapat ditentukan melalui 2 cara yaitu secara subyektif dan pengamatan secara obyektif, pengukuran kimia, fisik, dan mikroba. Pengukuran kualitas yoghurt dapat berlangsung kapan saja, tetapi biasanya berlangsung sekitar 24 jam setelah produksi dan jika memungkinkan terdiri dari pemeriksaan sensoris (rasa, aroma, penampakan luar, tekstur), mikroskopis, titrasi keasaman, $\mathrm{pH}$, komposisional, analisis (lemak, protein) dan ketahanan umur setelah 4 hari penyimpanan pada suhu $15^{\circ} \mathrm{C}$.

\section{GAMBARAN UMUM MITRA}

KOTA PELANGI singkatan dari Komunitas Wanita Pengusaha Jualan Dagangan Mandiri merupakan komunitas yang beranggotakan perempuan-perempuan kreatif yang memiliki jiwa wirausaha dan bertempat tinggal di kecamatan Pancoran. Komunitas ini mulai terbentuk sejak 2017 dengan Ibu Yuli sebagai penggagas sekaligus menjadi ketua komunitas saat ini.

Komunitas ini lahir sebagai bagian dari upaya pemberdayaan potensi perempuan dalam bidang kemandirian usaha. Setiap anggota komunitas ini memiliki minimal satu produk sebagai hasil darihome industry yang sedang ditekuni saat ini. Beberapa diantaranya menekuni kegiatan wirausaha ini berawal dari hobi, ada juga yang hanya diawali dengan asal coba saja dan ada beberapa yang memang menjadikan kegiatan wirausaha ini sebagai kegiatan pokok yang diharapkan dapat memperbaiki kondisi ekonomi keluarganya. Anggota komunitas memiliki semangat tinggi untuk terus memperbaiki kegiatan wirausahanya. Pada beberapa kesempatan, anggota komunitas berkumpul untuk saling berbagi informasi tentang bisnis maupun saling memberi saran untuk kebaikan bersama.

Kota Pelangi terbagi dalam beberapa divisi dengan tujuan untuk memberikan ruang yang lebih spesifik dalam berbagi informasi dan saran, serta memudahkan pengurus komunitas untuk melakukan treatment pelatihan yang tentunya berbeda kebutuhan untuk setiap divisi.

Pada divisi makanan, beberapa produk yang sudah ditekuni oleh anggotanya adalah siomay, rendang, susu kedelai, mie, roti, kue basah dan es krim dan lain sebagainya. Pada divisi fashion, anggotanya lebih dominan memproduksi fashion muslimah melalui toko online maupun toko offline yang dimiliki. Sedangkan pada divisihandicraft, beberapa produk yang masuk pada kategori ini adalah bross dan kerajinan flanel. Divisi terakhir yakni divisi retail, yang sebagian besarnya telah menjadi reseller online.

Kota Pelangi diharapkan dapat menjadi role model perempuan-perempuan secara khusus di wilayah Pancoran dan di seluruh Indonesia secara luas terkait dengan kemandirian dalam berwirausaha. Untuk mencapai harapan 
tersebut, dirasa perlu untuk melakukan beberapa pelatihan dan pendampingan yang mendukung untuk meningkatkan dan mengembangkan kegiatan bisnis yang saat ini sedang ditekuni (Asiah, 2019).

Sasaran masyarakat yang ditargetkan merupakan ibu-ibu dari kota pelangi yang sudah memiliki wirausaha baik dibidang makanan maupun non-makanan. Komunitas pelangi ini sebelumnya telah menjadi partner dalam program-program pengabdian yang diusung oleh ITP Universitas Bakrie.

\section{METODOLOGI PENELITIAN}

Kegiatan ini merupakan program pelatihan untuk pengembangan ilmu, disampaikan oleh para dosen yang kompeten dalam bidang pengolahan pangan. Adapun kegiatan telah diselenggarakan sekitar bulan OktoberNovember 2019.

Persiapan dilakukan satu bulan sebelum jadwal kegiatan. Persiapan yang dilakukan meliputi koordinasi topik dan wilayah kegiatan, survei lokasi, rapat koordinasi, dan penyiapan materi. Survei lokasi dilakukan untuk mengetahui kondisi lingkungan di lokasi sebenarnya dan fasilitas serta penunjang lainnya yang sudah tersedia.

Rapat koordinasi dilakukan untuk memilih materi ajar dan praktek yang akan disampaikan pada hari pelaksanaan. Pemilihan materi ajar disesuaikan dengan bidang keahlian dari masingmasing pengajar. Kegiatan pelatihan dilakukan dalam 1 hari selama 6 jam yang terbagi dalam 2 sesi dengan durasi masing-masing sesi adalah 3 jam. Sesi pertama disampaikan materi, lalu sesi kedua praktek pengolahan yoghurt.

Pengamatan terhadap hasil pelatihan dilakukan secara kualitatif. Terdiri dari proses pelatihan yang berlangsung dan juga tanggapan para peserta yang mengikuti acara.

\section{HASIL DAN PEMBAHASAN}

Pelatihan pembuatan yoghurt ini diikuti sekitar 30 peserta. Kegiatan dilakukan dengan pemaparan materi terlebih dahulu mengenai aspek mikrobiologis biakan bakteri asam laktat, proses fermentasi yang terjadi, proses pengolahan dengan teknik sederhana menggunakan peralatan sederhana yang ada di rumah. Setelah itu sampel produk yoghurt yang sudah dibuat sebelumnya dibagikan kepada peserta yang sudah terbagi kedalam kelompok, kemudian mengkreasikan dengan perisa seperti rasa strawberi, mangga, jeruk dan juga toping untuk mempercantik sekaligus menambah cita rasa pada yoghurt. Toping yang digunakan terdiri dari sereal, buah maupun coklat chip. Peserta melakukan dengan antusias dan kemudian mencicipi rasa yoghurtnya. Penilaian produk dilakukan dengan membandingkannya dengan produk benchmark (produk yang sudah beredar di pasaran) dalam bentuk deskripsi. Deskripsi secara keseluruhan mengenai hasil yoghurt yang telah dibuat a dalah rasanya enak, sedikit asam, tekstur lembut. 


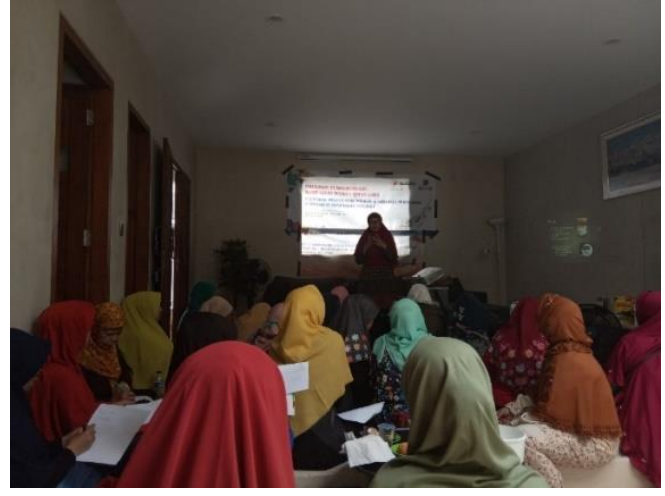

Gambar 1. Pemaparan Materi Pembuatan Yoghurt oleh Pembicara

(Sumber: dokumentasi pribadi)

Setelah berkreasi dengan produk yoghurt, peserta pelatihan diberikan keterampilan pembuatan yoghurt dengan langkah sebagai berikut: melarutkan susu bubuk dan mempasteurisasi susu dengan temperature $63^{\circ} \mathrm{C}$, kurang lebih selama 3-5 menit. Setelah itu, susu dipindahkan kedalam plastik tahan panas yang disimpan pada box, lalu diinokulasikan dengan yoghurt set yang berisi kultur aktif. Setelah itu diinkubasi. Yoghurt akan dihasilkan keesokan harinya.

Susu bubuk instan full cream diinokulasikan dengan biakan dari yoghurt akan menghasilkan yoghurt dengan kekentalan yang dapat disesuaikan dengan waktu fermentasi. Cita rasa asam yang dihasilkan dapat distandarkan dengan penambahan asam organik yang food grade. Perisa dapat ditambahkan kedalam yoghurt sesuai dengan rasa yang diinginkan.

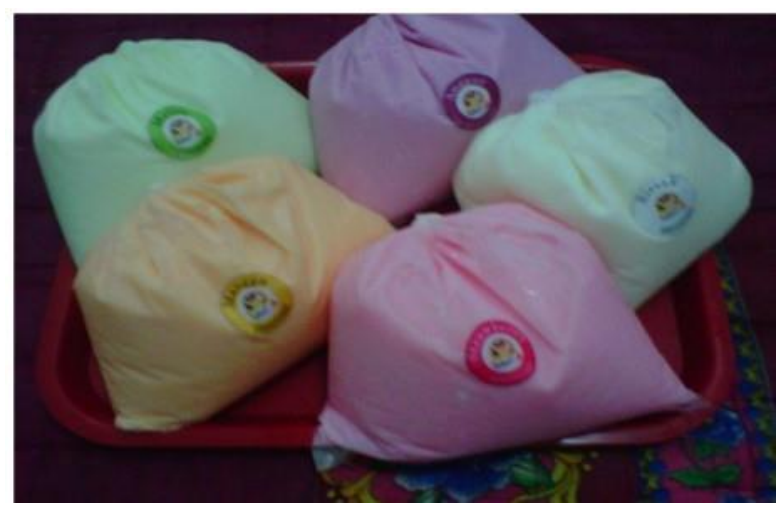

Gambar 2. Yoghurt dari Bahan Baku Susu Bubuk Instan Full Cream

(Sumber: dokumentasi pribadi)

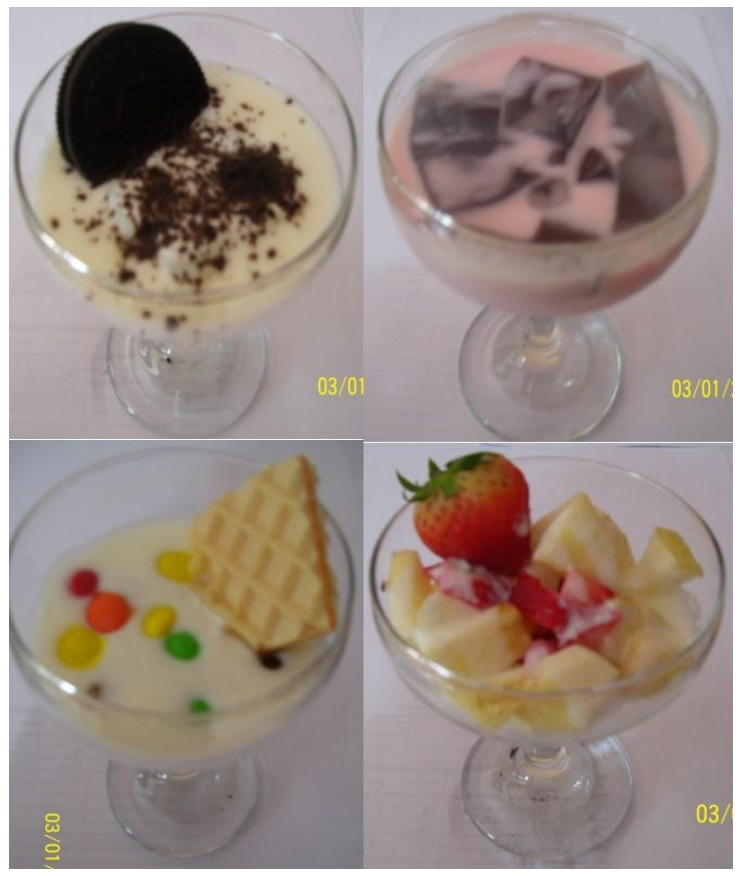

Gambar 3. Aneka Olahan Yoghurt (Sumber: dokumentasi pribadi)

Produk yoghurt dapat dikemas dalam kemasan cup yang diseal dengan mesin pengemas. Untuk menghasilkan yoghurt yang berkualitas rantai dingin digunakan dalam tahap penyimpanan maupun distribusi. 


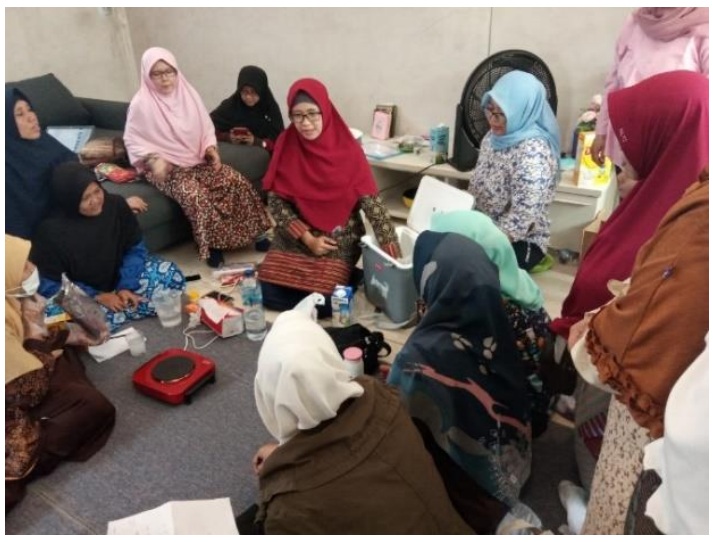

Gambar 4. Simulasi pembuatan yoghurt (Sumber: dokumentasi pribadi)

Para peserta menilai yoghurt yang dikreasikan dengan aneka perisa dan toping. Dari analisis rasa, sebagian besar peserta menyimpulkan rasanya telah sesuai dengan yoghurt yang diolah dari bahan baku susu segar. Lalu dari segi tekstur yang dihasilkan cukup baik dan cukup kental seperti yang ada pada yoghurt dalam kemasan yang telah dijual di pasaran.

Dari analisis tersebut dapat disimpulkan bahwa yoghurt yang terbuat dari susu bubuk instan full cream dapat memenuhi kriteria yoghurt pada umumnya, yaitu yoghurt yang bercita rasa asam dan bertekstur kental.

Namun, dari segi rasa ketika yoghurt belum dicampur dengan perisa, rasa yang dihasilkan tidak terlalu asam. Sehingga memang diperlukan adanya perisa tambahan untuk menstandarkan rasa asam yang ada.

Menurut Syainah, dkk (2014), tidak terdapat pengaruh jenis susu terhadap daya terima warna, aroma, kekentalan pada yoghurt yang diinkubasi pada susu yang sama, kecuali berkaitan dengan rasa. Hal ini menandakan bahwa jenis susu bubuk instan full cream yang diolah dengan baik akan menghasilkan yoghurt yang memiliki kualitas yang cukup baik dalam hal ini berkaitan dengan tekstur.

Dalam setiap kegiatan, selalu dilakukan proses evaluasi. Pada pelatihan ini, yoghurt yang diproduksi saat kegiatan berlangsung tidak dapat diamati oleh pemateri karena dilakukan keesokan harinya. Informasi yang disampaikan dari peserta menjelaskan bahwa yoghurt sedikit tumpah karena penyimpanan yang kurang tepat. Namun hal tersebut tidak menjadi kendala karena peserta sudah mendapat informasi yang jelas dan lengkap, serta dapat mengetahui proses secara lengkap secara simulasi.

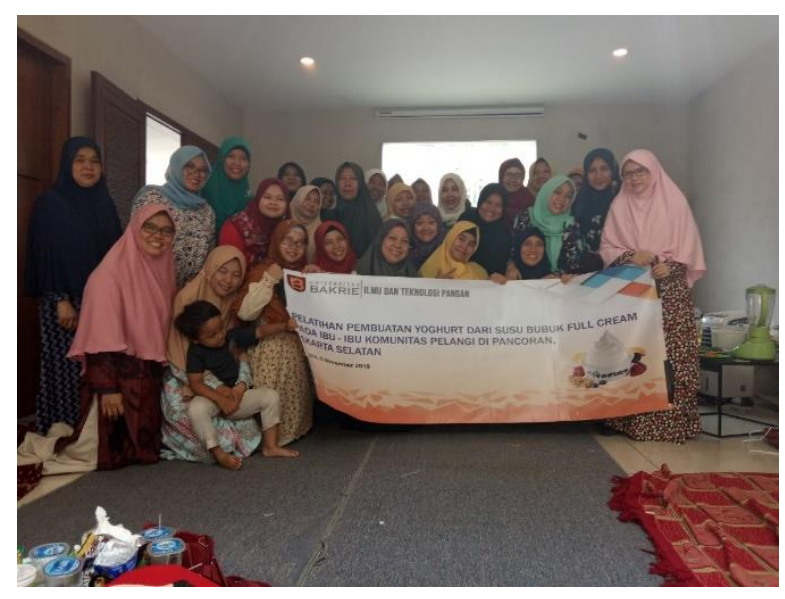

Gambar 5. Pembicara dan Peserta Berfoto Bersama Usai Kegiatan Berlangsung

(Sumber: dokumentasi pribadi)

\section{KESIMPULAN}

Yoghurt merupakan minuman yang sering dinikmati karena rasa dan khasiatnya. Bahan baku pembuatan yoghurt tidak harus dari susu segar, melainkan dapat digunakan susu bubuk kemasan yang dijual di pasaran. Yoghurt dari susu bubuk bisa bersaing dengan produk yoghurt 
dari susu segar. Ditambah dengan bahan tambahan pangan lain dan kemasan yang tepat, produk ini tentu dapat bersaing di pasaran. UKM Kota Pelangi pelangi memiliki kelebihan dalam akses yang strategis untuk penjualan. Sehingga pelatihan ini di rasa tepat untuk dilakukan.

\section{UCAPAN TERIMA KASIH}

Terima kasih kepada Lembaga Pengabdian Masyarakat Universitas Bakrie, yang telah mendanai dan memfasilitasi untuk kegiatan PkM ini.

\section{DAFTAR PUSTAKA}

Asiah, N. (2019). Kota Pelangi: Komunitas Wanita Pengusaha Jualan Dagangan Mandiri. Kota Pelangi Diakses dari http://wanitabe rdaya.com.

Deeth, H. C., \& Tamime, A. Y. (1981). Yoghurt: nutritive and therapeutic aspects. J.Food Prot, 44, 78-86.

Jatmika, S. E. D. J., \& Hastuti, S. K. W. (2019). Pelatihan dan Pendampingan Pembuatan Aneka Olahan Makanan Pendamping ASI (MPASI) Berbahan Pangan Lokal Kaya Nutrisi. Gemmasika, 3, 115-124.

Peraturan Menteri Pemberdayaan Perempuan dan Perlindungan Anak Republik Indonesia Nomor 2 Tahun 2016 Pedoman Umum Pembangunan Industri Rumahan untuk Meningkatkan Kesejahteraan Keluarga melalui Pemberdayaan Perempuan. Jakarta.
Rukmana \& Rahmat. (2001). Yoghurt dan Karamel Susu. Yogyakarta: Kanisius.

Susilorini, T. E. \& Sawitri, M. E. (2007). Produk Olahan Susu. Jakarta: Penebar Swadaya.

Surono, I.S. (2004). Probiotik Susu Fermentasi dan Kesehatan. Yayasan Pengusaha Makanan dan Minuman Seluruh Indonesia (YAPMMI). TRICK, 31- 32.

Syainah, E., Novita, S., \& Yanti, R. (2014). Kajian Pembuatan Yoghurt dari Berbagai Jenis Susudan Inkubasi yang Berbeda Terhadap Mutu dan Daya Terima. Jurnal Skala Kesehatan, 5(1).

Wahyudi, M. (2006). Proses Pembuatan dan Analisis Mutu Yoghurt. Bogor: Balai Besar Penelitian dan Pengembangan Pascapanen Pertanian.

Widowati, S., \& Misgiyarta. (2009). Efektifitas Bakteri Asam Laktat (BAL) dalam Pembuatan Produk Fermentasi Berbasis Protein/Susu Nabati. Prosiding. Balai Penelitian Bioteknologi dan Sumber Daya Genetik Pertanian.

Winarno, F.G. (2003). Kimia Pangan dan Gizi. Jakarta: PT Gramedia Pustaka Utama. 
Indonesian Journal for Social Responsibility (IJSR) Vol. 2, No. 01, (2020), hal. 1-9 